\title{
Carbon, Nitrogen and Phosphorus Budget for the Culture of Indian Major Carps with Different Stocking Density
}

\author{
Adhikari $\mathbf{S}^{1^{*}}$, Pani $\mathrm{KC}^{1}$, Mishra $\mathbf{B}^{1}$, Jena $\mathrm{JK}^{2}$ and Jayasankar $\mathbf{P}^{1}$
}

${ }^{1}$ Central Institute of Freshwater Aquaculture, P.O.-Kausalyaganga, Bhubaneswar, India

${ }^{2}$ National Bureau of Fish Genetic Resources, Canal Ring Road, P.O. Dilkusha, Lucknow ,India

*Corresponding author: Adhikari S, Principal Scientist, Central Institute of Freshwater Aquaculture, P.O.-Kausalyaganga, Bhubaneswar-751002, India, Tel: 91-674-2465446; E-mail: subhendu66@rediffmail.com

Rec date: May 22, 2014; Acc date: Jul 29, 2014; Pub date: Aug 09, 2014

Copyright: ( 2014 Adhikari S, et al. This is an open-access article distributed under the terms of the Creative Commons Attribution License, which permits unrestricted use, distribution, and reproduction in any medium, provided the original author and source are credited.

\begin{abstract}
Nutrient budget was performed for the culture of Indian major carps; Catla catla (catla), Labeo rohita (rohu) and Cirrhinus mrigala (mrigal) in twelve fishponds, each of 0.04 ha water area. The stocking densities of carps were 7,$500 ; 10,000$ and 12,500 no. /ha (four replications for each stocking density and the ratio of each species was 1:1:1) and the average weights of catla, rohu and mrigal fingerlings were $6.5 \pm 0.5,5.0 \pm 0.4$ and $3.5 \pm 0.4 \mathrm{~g}$, respectively. The culture period was six months. Cow dung@14,000 kg/ha/yr was applied fortnightly as manure. Urea@200 kg/ha/yr and single super phosphate@300kg/ha/yr were applied fortnightly as fertilizers. The fish were fed with an admixture of groundnut oil cake and rice polish in the ratio of 1:1@2\% body weight of their biomass. The budget showed that recovery (in terms of fish yield) of nitrogen $(\mathrm{N})$ decreased from 43 to $24 \%$ and the same for phosphorus $(P)$ also decreased from 16 to $9 \%$ with increase in stocking density. The recovery of organic carbon (OC) decreased from 28 to $16 \%$ with increase in stocking density from 7,500/ha to 12,500/ha. Effluent water (pond water at the time of harvest) accounted for 1.8 to $3.0 \% \mathrm{~N}, 2.5$ to $4.0 \% \mathrm{P}$ and 2.5 to $5.0 \%$ OC of the total inputs while bottom sediment accounted for 41 to $50 \% \mathrm{~N}, 70$ to $75 \% \mathrm{P}$ and 62 to $64 \%$ OC of the total inputs, respectively. Nutrient accumulation increased in both the effluent water and bottom sediment with increase in stocking density.
\end{abstract}

Keywords: Nutrient budget; Indian major carps; Stocking density; Nutrient accumulation; Sediment; Effluent water; Catla catla; Labeo rohita; Cirrhinus mrigala

\section{Introduction}

Aquaculture activities involve a variety of inputs for fish production including manures, fertilizers, feed and a combination of all these things. With high fertilization rate, the nutrients assimilated in fish biomass were estimated to be less than $20 \%$ for nitrogen $(\mathrm{N})$ and $10 \%$ for phosphorus (P) [1]. Most of those lost nutrients are distributed in water, fish biomass and sediments of the pond systems. It is generally believed that a large proportion of nutrients received in ponds ends up in pond muds and discharged effluents [2]. To reduce the nutrient losses in discharged water, it is essential to estimate the nutrient budgets to assess the fate of nutrients added to the pond culture systems. Nutrient budgets could permit quantification of potential pollution impact of a specific pond management strategy. Chemical budgets have been formulated for experimental ponds containing channel catfish [3], striped bass [4], tilapia [5] and high densities of shrimp [6,7]. Nitrogen (N) and Phosphorus(P) budgets were formulated for commercial shrimp ponds in Thailand [8,9], extensive shrimp ponds in Bangladesh [10], semi-intensive shrimp farms in Mexico [11], intensive shrimp farms in Australia. The nutrient budget for Indian major carp's culture is scanty. The objective of the present investigation is to assess the nutrients $\mathrm{N}, \mathrm{P}$, and organic carbon (OC) uptake by the fish, Indian major carps at three different stocking density levels.

\section{Materials and Methods}

For the study of nutrient budget, 12 ponds of 0.04 ha area each in the farm of the institute located at the Khordha district of Odisha, India with a mean water depth of $1.2 \mathrm{~m}$ were selected. At the time of pond preparation, $10 \%$ of total organic fertilizer (cow dung) was applied. Lime@200 kg/ha was applied at the time of pond preparation.

The fingerlings of Catla catla (catla), Labeo rohita (rohu) and Cirrhinus mrigala (mrigal) were stocked in these ponds at a ratio of 1:1:1 at three stocking density levels of 7,500/ha, 10,000/ha and $12,500 /$ ha, each with four replications. The average weights of catla, rohu and mrigal fingerlings were $6.5 \pm 0.5,5.0 \pm 0.4$ and $3.5 \pm 0.4 \mathrm{~g}$, respectively at the initial stocking time. The cow dung@14,000 $\mathrm{kg} / \mathrm{ha} / \mathrm{yr}$ was applied to these ponds. The inorganic fertilizers, urea was applied@200 kg/ha/yr and Single Super Phosphate (SSP) was applied@300 kg/ha/yr. The organic fertilizer was applied to these ponds in equal amounts at weekly intervals while inorganic fertilizers were applied to these ponds in equal amounts at fortnight intervals. The fish were fed with an admixture of Groundnut Oil Cake (GOC) (43.75\% protein content) and Rice Polish (RP) (16.25\% protein content) in the ratio of 1:1@2\% body weight of their biomass. Feed was applied to the ponds by keeping the feeds in a cotton bag with six to eight holes tighten with a bamboo stick. Two bamboo sticks were used for this purpose in a pond. Lime was applied to these ponds@200 $\mathrm{kg} / \mathrm{ha}$ as and when required throughout the culture period. The culture period was six months. At harvest time, the average weight of catla, rohu and mrigal were $400 \pm 40,300 \pm 20$ and $200 \pm 30 \mathrm{~g}$, respectively, in the ponds with a stocking density of $7,500 /$ ha. The production level in these ponds was $1,890 \mathrm{~kg} / \mathrm{ha} / 6$ months with a survival rate of $84 \%$. At harvest time, the average weight of catla, rohu 
and mrigal were $280 \pm 30,170 \pm 30$ and $140 \pm 40 \mathrm{~g}$, respectively, in the ponds with a stocking density of $10,000 /$ ha. The production level in these ponds was $1,564 \mathrm{~kg} / \mathrm{ha} / 6$ months with a survival rate of $80 \%$. The average weight of catla, rohu and mrigal were $140 \pm 50,115 \pm 40$ and $100 \pm 20 \mathrm{~g}$, respectively, in the ponds at harvest time with a stocking density of $12,500 /$ ha. The production level in these ponds was $1,118 \mathrm{~kg} / \mathrm{ha} / 6$ months with a survival rate of $76 \%$.

\begin{tabular}{|c|c|c|c|c|c|c|}
\hline \multirow{3}{*}{$\begin{array}{l}\text { Parameters } \\
\text { Inputs }\end{array}$} & \multicolumn{6}{|c|}{$\mathrm{N}$ levels at different stocking densities } \\
\hline & \multicolumn{2}{|l|}{$7,500 / \mathrm{ha}$} & \multicolumn{2}{|l|}{$10,000 / \mathrm{ha}$} & \multicolumn{2}{|l|}{$12,500 / \mathrm{ha}$} \\
\hline & $\mathrm{Kg} / \mathrm{ha}$ & $\%$ & $\mathrm{Kg} / \mathrm{ha}$ & $\%$ & $\mathrm{Kg} / \mathrm{ha}$ & $\%$ \\
\hline Inflow water & $1.20 \pm 0.05$ & 0.94 & $1.20 \pm 0.05$ & 0.92 & $1.20 \pm 0.05$ & 0.9 \\
\hline Cow dung & $36.75 \pm 2.25$ & 28.83 & $36.75 \pm 2.25$ & 28.22 & $36.75 \pm 2.25$ & 27.66 \\
\hline GOC & $17.50 \pm 1.50$ & 13.73 & $19.32 \pm 1.60$ & 14.83 & $20.93 \pm 1.70$ & 15.75 \\
\hline RP & $6.57 \pm 0.23$ & 5.15 & $7.18 \pm 0.32$ & 5.51 & $7.77 \pm 0.33$ & 5.85 \\
\hline Urea & $64.37 \pm 3.37$ & 50.5 & $64.37 \pm 3.37$ & 49.41 & $64.37 \pm 3.37$ & 48.46 \\
\hline Stocked fish & $1.09 \pm 0.10$ & 0.85 & $1.45 \pm 0.15$ & 1.11 & $1.82 \pm 0.20$ & 1.38 \\
\hline Total input & $127.48 \pm 2.68$ & 100 & $130 \pm 2.12$ & 100 & $132.84 \pm 3.26$ & 100 \\
\hline \multicolumn{7}{|l|}{ Output } \\
\hline Effluent water & $2.40 \pm 0.10$ & 1.85 & $3.00 \pm 0.16$ & 2.3 & $3.36 \pm 0.17$ & 2.53 \\
\hline Harvested fish & $54.99 \pm 3.11$ & 43.18 & $45.25 \pm 3.10$ & 34.74 & $32.08 \pm 2.82$ & 24.15 \\
\hline Sediment accumulation & $52.50 \pm 4.45$ & 41.18 & $60.50 \pm 5.66$ & 46.44 & $66.42 \pm 6.12$ & 50 \\
\hline Others & $17.59 \pm 2.21$ & 13.79 & $21.52 \pm 2.32$ & 16.52 & $30.98 \pm 3.02$ & 23.32 \\
\hline
\end{tabular}

Table 1: Input, output and balance of nitrogen $(\mathrm{N})$ in the polyculture of Indian major carps

The N, P and OC input, output, uptake and accumulation in the culture system during the culture period were measured. The nutrient budget of N, P, and OC were calculated based on inputs from water, fertilizer and feed; and outputs were calculated based on harvested fish, drained water and sediment. Nutrient input and output in the form of water was calculated by multiplying the nutrient concentration with total water volume. Nutrient input in the form of water represents nutrient contained in water on the day of fish stocking, as water sample was collected on the same day prior to fish stocking. Nutrient output in the form of water represents nutrient contained in water on the harvest day; column water sample was taken to measure final nutrient concentration in water prior to pond draining.

Soil samples were collected by taking six cores (up to $15 \mathrm{~cm}$ depth) from each pond, and mixed in a composite sample for analysis; final sample was taken on the harvest day prior to pond draining. Nutrient concentration in the initial and final soil sample was measured to calculate nutrient surplus in the soil over the study period; the calculation was as follows:

Total nutrient content in sediment $=$ nutrient concentration in the sediment $\times$ total mass, total mass was calculated from mean bulk density.

Soil sample taken before fish stocking and post harvest were analyzed for total nitrogen [12] and total phosphorus content was analyzed by persulphate digestion method and followed by ascorbic method [13]. Total organic carbon of the soil was determined using
Walkley and Black [14] rapid titration method. Total nitrogen, phosphorus and organic carbon concentration was also analyzed for fish feed (ground nut oil cake, rice polish), organic fertilizer (cow dung), carcasses of harvested fish following the methods used for sediment.

Nutrient input in the form of feed was calculated as follows:

Nutrient $(\mathrm{N} / \mathrm{P} / \mathrm{C})$ in feed $=$ nutrient concentration in feed $\times$ total amount of feed supplied. Nutrient output in the form of fish was calculated as follows:

Nutrient $(\mathrm{N} / \mathrm{P} / \mathrm{C})$ in fish $=$ nutrient concentration in fish carcasses $x$ total fish biomass [15]. Mean fish weight was determined at initial and final harvest.

Water quality of fish culture ponds measured biweekly at $10.00 \mathrm{~h}$. Total ammonia nitrogen in water was measured by phenate method [13], nitrite nitrogen was analyzed by colorimetric method using the Griess reaction [13], nitrate nitrogen was measured using brucine sulphate method [13], Soluble Reactive Phosphate (SRP) was determined by ascorbic acid method [13], and total phosphorus was estimated by acid digestion [13]. Total alkalinity and Chlorophyll-a concentration were determined by APHA [13].Total organic carbon was determined by APHA [13]. Temperature, Dissolve Oxygen (DO), and $\mathrm{pH}$ (at $20 \mathrm{~cm}$ below the water surface) were measured weekly in situ.

Analysis of Variance (ANOVA) with Duncan Multiple Range Test (DMRT) was applied to determine the significant differences among 
the nutrient uptake by the fish at different stocking density levels using the SAS computer software. The significant level was tested at $5 \%$ level.

\section{Results and Discussion}

Nutrient budget revealed that fertilizer was the major input of $\mathrm{N}$ and $\mathrm{P}$. The $\mathrm{N}$ input in the form of inorganic fertilizer (urea) was around $50 \%$ while $\mathrm{P}$ input through inorganic fertilizer (SSP) was $62 \%$ of the total inputs. The OC input in the form of organic fertilizer (cow dung) was $80 \%$ of total inputs. The $\mathrm{N}$ input in the form of supplementary feed (GOC and RP) increased from 18.88 to $21.60 \%$ with an increase in the stocking densities from 7,500 /ha to 12,500 /ha (Table 1), while the $\mathrm{P}$ input in the form of feed increased from 7.25 to $8.48 \%$ with an increase in the stocking densities (Table 2). The OC in the form of feed increased from 16.80 to $19.22 \%$ with an increase in stocking densities (Table 3). It is predictable that external nutrient incorporation in excess may cause a nutrient deposition at sediment. The $\mathrm{N}$ accumulation in the sediment increased from 41.18 to $50.00 \%$, the $\mathrm{P}$ accumulation varied from 70.00 to $75.48 \%$, and the OC accumulation was in the range of 62.37 to $64.00 \%$ in the culture system.

\begin{tabular}{|c|c|c|c|c|c|c|}
\hline Parameters & $P$ levels at $d$ & densitie & & & & \\
\hline & $7,500 / \mathrm{ha}$ & & $10,000 / \mathrm{ha}$ & & $12,500 / \mathrm{ha}$ & \\
\hline Inputs & $\mathrm{Kg} / \mathrm{ha}$ & $\%$ & $\mathrm{Kg} / \mathrm{ha}$ & $\%$ & $\mathrm{Kg} / \mathrm{ha}$ & $\%$ \\
\hline Inflow water & $0.35 \pm 0.02$ & 0.65 & $0.35 \pm 0.02$ & 0.65 & $0.35 \pm 0.02$ & 0.64 \\
\hline Cow dung & $15.75 \pm 1.16$ & 29.36 & $15.75 \pm 1.16$ & 29.12 & $15.75 \pm 1.16$ & 28.9 \\
\hline GOC & $1.62 \pm 0.10$ & 3.02 & $1.79 \pm 0.11$ & 3.3 & $1.94 \pm 0.12$ & 3.55 \\
\hline $\mathbf{R P}$ & $2.27 \pm 0.16$ & 4.23 & $2.48 \pm 0.17$ & 4.58 & $2.69 \pm 0.18$ & 4.93 \\
\hline SSP & $33.50 \pm 2.12$ & 62.44 & $33.50 \pm 2.12$ & 61.94 & $33.50 \pm 2.12$ & 61.46 \\
\hline Stocked fish & $0.16 \pm 0.01$ & 0.3 & $0.22 \pm 0.01$ & 0.41 & $0.28 \pm 0.02$ & 0.52 \\
\hline Total input & $53.65 \pm 2.76$ & 100 & $54.09 \pm 2.77$ & 100 & $54.51 \pm 2.80$ & 100 \\
\hline Output & & & & & & \\
\hline Effluent water & $1.20 \pm 0.06$ & 2.23 & $1.68 \pm 0.07$ & 3.1 & $1.92 \pm 0.08$ & 3.52 \\
\hline Harvested fish & $8.50 \pm 0.20$ & 15.84 & $6.99 \pm 0.18$ & 12.93 & $4.96 \pm 0.14$ & 9.1 \\
\hline Sediment accumulation & $40.50 \pm 3.12$ & 75.48 & $38.40 \pm 3.36$ & 71 & $38.16 \pm 3.20$ & 70 \\
\hline Others & $3.45 \pm 0.15$ & 6.45 & $7.02 \pm 0.20$ & 12.97 & $9.47 \pm 0.23$ & 17.38 \\
\hline
\end{tabular}

Table 2: Input, output and balance of phosphorus $(\mathrm{P})$ in the polyculture of Indian major carps

In addition, nutrient budgets showed that during the culture period some of the $\mathrm{N}, \mathrm{P}$, and $\mathrm{OC}$ went unaccounted (i.e. others). Unaccounted $\mathrm{N}$ increased from 13.79 to $23.32 \%$ of the total nutrient retention, while unaccounted $\mathrm{P}$ increased from 6.45 to $17.38 \%$ with an increase of stocking densities in the culture system. Unaccounted OC was 6.75 to $16.82 \%$. The $\mathrm{N}, \mathrm{P}$, and OC output in the discharged water during harvest were $2.22,2.95$, and $2.93 \%$, respectively. Nitrogen, phosphorus and organic carbon retained (recovered) in the fish were $34.53,10.88$, and $22.20 \%$, respectively of the total inputs. The budget showed that recovery (in terms of fish yield) of $\mathrm{N}$ decreased from 43.18 to $24.15 \%$ and the same for $\mathrm{P}$ also decreased from 15.84 to $9.10 \%$ with increase in stocking density. The recovery of OC decreased from 28.30 to $15.95 \%$ with increase in stocking density from $7,500 /$ ha to $12,500 /$ ha.

At $10,000 /$ ha stocking density, $\mathrm{N}$ was utilized by $34.74 \%$, P was utilized by $12.93 \%$, and C was utilized by $22.88 \%$, respectively, by the fishes. At the same stocking density, N, P, C accumulated in the sediment was $46.44,71$, and $63.77 \%$, respectively.
In polyculture system, it is difficult to estimate the nutrient budget separately for each individual species, as they have different feed behavior and nutrient intake capability. For this, nutrient budget could be done in the monoculture practices. However, in the present study, the nutrient utilization by the three different fishes (Indian major carps) was estimated jointly.

These data indicated significant $(\mathrm{Fcal}=54.41, \mathrm{Ftab}=5.14$ at $5 \%$ level for N, Fcal $=81.68, \mathrm{Ftab}=5.14$ at $5 \%$ level for $\mathrm{P}$, and Fcal $=172.42$, Ftab $=5.14$ at $5 \%$ level for OC) differences in nutrient uptakes by the fish among different stocking densities. The Critical Difference (CD) for $\mathrm{N}$ was calculated as 5.41 at $5 \%$ level, and the $\mathrm{N}$ uptake were $54.99,45.25$, and $32.08 \mathrm{~kg}$ at three stocking densities of 7,500/ha, 10,000/ha, and $12,500 /$ ha, respectively. Thus, the $\mathrm{N}$ uptake at three different stocking densities differed significantly $(\mathrm{P}<0.05)$ from one another. The $\mathrm{CD}$ for $\mathrm{P}$ was estimated at 0.672 at $5 \%$ level, and the $\mathrm{P}$ uptake at three stocking densities of $7,500 /$ ha, $10,000 /$ ha, and $12,500 /$ ha were $8.50,6.99$, and $4.96 \mathrm{~kg}$, respectively. Therefore, the $\mathrm{P}$ uptake at three different stocking densities differed significantly $(\mathrm{P}<0.05)$ from one another. The calculated CD for OC was 14.02 at $5 \%$ level, and the OC uptake at three stocking densities of 7,500/ha, 10,000/ha, and 12,500/ha were 
Page 4 of 6

$255.15,209.94$, and $148.83 \mathrm{~kg}$, respectively. Thus, the OC uptake at three different stocking densities differed significantly $(\mathrm{P}<0.05)$ from one another.

In aquaculture, it is well accepted that the stocking density is critical factor for many aquatic animal for their growth and survival [16,17]. Stocking density is related to the volume of water per fish. Increase in stocking density results in increasing stress, which leads to higher energy requirements, causing a reduction in growth rate and food utilization [18]. It is directly related with the competition for food and space $[16,18]$. Generally, fish needs to compete less for food and space in lower stocking density than the higher stocking density. The present study also demonstrates about the effect of stocking density on its growth and survival, where the growth and survival were higher in ponds with lower stocking density than the ponds with higher stocking density. Thus, in higher stocking density, the nutrient utilization was also significantly less compared to the lower stoking density.

Sediment plays an important role in the balance of an aquaculture system; it can act as a buffer in water nutrient concentration [20]. The sediment layer of few centimeter depths contains more nutrients than the content of the water column [21]. The large amount of unaccounted for nitrogen could be probably due to losses through denitrification process in the sediment. Diab and Shilo [22] reported that when ponds were refilled, anaerobic conditions developed beneath the soil surface, and nitrate was converted to nitrogen gas by denitrification. Sedimentation is generally considered a main mechanism for $\mathrm{P}$ loss in ponds because sediments are known to have a strong affinity for phosphorus [23]. Denitrification and ammonia volatilization are two potential losses of $\mathrm{N}$ that are not often measured directly in the culture systems. In the present study, these losses are estimated indirectly as the difference between the $\mathrm{N}$ inputs and outputs. The $\mathrm{N}$ loss was estimated at 13.79 to $23.32 \%$ through these processes and the loss increased with increase in stocking density. However, variable results have been reported in different studies. Most of the studies estimated less than $15 \%$ of $\mathrm{N}$ as unaccounted $[7,8]$. In some other studies, higher losses of $\mathrm{N}$ ranging from 27.4 to $66 \%$ have also been reported $[3,24]$.

\begin{tabular}{|c|c|c|c|c|c|c|}
\hline \multirow{3}{*}{$\begin{array}{l}\text { Parameters } \\
\text { Inputs }\end{array}$} & \multicolumn{6}{|c|}{ OC levels at different stocking densities } \\
\hline & \multicolumn{2}{|l|}{$7,500 / \mathrm{ha}$} & \multicolumn{2}{|l|}{$10,000 /$ ha } & \multicolumn{2}{|l|}{$12,500 / \mathrm{ha}$} \\
\hline & $\mathrm{Kg} / \mathrm{ha}$ & $\%$ & $\mathrm{Kg} / \mathrm{ha}$ & $\%$ & $\mathrm{Kg} / \mathrm{ha}$ & $\%$ \\
\hline Inflow water & $10.25 \pm 1.15$ & 1.14 & $10.25 \pm 1.15$ & 1.12 & $10.25 \pm 1.15$ & 1.1 \\
\hline Cow dung & $735.00 \pm 15.50$ & 81.5 & $735.00 \pm 15.50$ & 80.1 & $735.00 \pm 15.50$ & 78.78 \\
\hline GOC & $70.75 \pm 5.25$ & 7.84 & $77.25 \pm 5.30$ & 8.42 & $83.72 \pm 5.76$ & 8.97 \\
\hline RP & $80.75 \pm 5.50$ & 8.96 & $88.32 \pm 5.70$ & 9.62 & $95.68 \pm 6.00$ & 10.25 \\
\hline Stocked fish & $5.06 \pm 0.20$ & 0.56 & $6.73 \pm 0.24$ & 0.74 & $8.45 \pm 0.30$ & 0.9 \\
\hline Total input & $901.81 \pm 19.19$ & 100 & $917.55 \pm 2.12$ & 100 & $933.10 \pm 21.23$ & 100 \\
\hline \multicolumn{7}{|l|}{ Output } \\
\hline Effluent water & $23.25 \pm 2.35$ & 2.58 & $27.36 \pm 2.40$ & 2.98 & $30.09 \pm 2.50$ & 3.23 \\
\hline Harvested fish & $255.15 \pm 10.50$ & 28.3 & $209.94 \pm 11.80$ & 22.88 & $148.83 \pm 7.55$ & 15.95 \\
\hline Sediment accumulation & $562.50 \pm 18.50$ & 62.37 & $580.50 \pm 20.12$ & 63.27 & $597.18 \pm 23.10$ & 64 \\
\hline Others & $60.91 \pm 10.62$ & 6.75 & $99.75 \pm 11.55$ & 10.87 & $157.00 \pm 13.40$ & 16.82 \\
\hline
\end{tabular}

Table 3: Input, output and balance of organic carbon (OC) in the polyculture of Indian major carps

The water quality of these fish culture ponds are presented in Table 4 and were as follows: Water $\mathrm{pH}$ ranged from 7.3 to 8.0 throughout the experimental period. Overall DO concentration varied from 4.8 to 5.5 $\mathrm{mg} / \mathrm{l}$. The $\mathrm{NH}_{4}-\mathrm{N}, \mathrm{NO}_{2}-\mathrm{N}$ and $\mathrm{NO}_{3}-\mathrm{N}$ ranged from 0.015 to 0.12 , 0.005 to 0.08 and 0.040 to $0.20 \mathrm{mg} / \mathrm{l}$, respectively. The soluble orthophosphate ranged from 0.003 to $0.02 \mathrm{mg} / \mathrm{l}$ while total phosphate ranged from 0.008 to $0.05 \mathrm{mg} / \mathrm{l}$. Total dissolved organic carbon ranged from 1.8 to $4.0 \mathrm{mg} / \mathrm{l}$ in the water. The total alkalinity concentrations varied from 80 to $140 \mathrm{mg} / \mathrm{l}$ as $\mathrm{CaCO}_{3}$. Overall mean of Secchi disk depths ranged from 12 to $24 \mathrm{~cm}$. Chlorophyll-a concentration increased with the progress of culture, and at the end of the culture period, chlorophyll-a reached as high as $0.40 \mathrm{mg} / \mathrm{l}$ from $0.20 \mathrm{mg} / \mathrm{l}$. The water quality was optimum for carp culture, though the nitrogen in different forms increased with increase in stocking density.
The effluent water after the fish harvest contained 2.40 to $3.36 \mathrm{~kg} / \mathrm{ha}$ of N, 1.20 to $1.92 \mathrm{~kg} / \mathrm{ha}$ of $\mathrm{P}$, and 23.25 to $30.09 \mathrm{~kg} / \mathrm{ha}$ of OC, respectively. The nutrient contents in the effluent increased with increase in stocking density. The net loads of $\mathrm{N}$ and $\mathrm{P}$ in effluent were $16.43 \mathrm{~kg} / \mathrm{hm}^{2} /$ cycle and $2.16 \mathrm{~kg} / \mathrm{hm}^{2} /$ cycle, respectively, while the COD load was $-17.88 \mathrm{~kg} / \mathrm{hm}^{2} /$ cycle in Chinese mitten crab (Eriocheir sinensis) farm ponds in the eastern part of Taihu Lake, China [25].

The nutrient loss through the effluent water and sediment could be reduced by different management practices. For this, calculated amount of fertilizers should be applied. Feed should be applied through demand feeders or through bags so that wastages of feed could be minimized. Very high quality feed should be applied so that maximum feed could be utilized by the fishes. Water and sediment 
quality should be monitored properly. However, the effluent water from the fish ponds could be used in different ways. Not all the N, P, and OC are discharged directly into any water bodies. Some fish farm directly discharge into rice fields or gardens for vegetables cultivation [26], and some nutrients will be retained in the sludge of ponds or taken up by other biota in the environment. The development of Better Management Practices (BMPs) and the application there of through a cluster approach (NACA) will lead to further betterment in fertilizers and feed efficacies and water management regimes, such as through the introduction of "water calenders" in the carp farming sector leading to significant reductions in N, P and OC discharge levels and thereby contribute to the sustainability of the sector and to improved environmental integrity [27].

The fish pond effluents containing the amount of different nutrients could enrich immediate water bodies. In the wake of climate change and mitigating measure of carbon sequestration, studies on the Amazon have demonstrated that nutrient discharge from rivers through increased diazotrophy could enhance carbon sequestration $[28,29]$. As such the Indian major carp farming system in the country could also be helpful in sequester carbon in significant quantities in the long run.

\section{Conclusion}

The present study showed that recovery (in terms of fish yield) of $\mathrm{N}$, $\mathrm{P}$, and $\mathrm{OC}$ decreased significantly $(\mathrm{P}<0.05)$ with increase in stocking density. The sediment accumulated more than $40 \%$ N, $70 \%$ P, and $60 \%$ OC, respectively irrespective of stocking density. High nutrient content of the pond bottom sediment makes it suitable for using as fertilizer but this could be done judiciously so that the crop soils could not be polluted. The harvested water contained appreciable amount of nutrients that was also increased with increasing stocking density. These nutrients enriched pond waters should be used as liquid fertilizer for horticultural crops. However, further research is essential for the utilization of pond sediment as fertilizer and pond water as irrigation water as well as liquid fertilizer. In addition, the appropriate rationing and use of high quality feeds for maximizing growth while minimizing waste losses would help to lessen the potential environmental impacts of intensive carp culture practices. Thus, proper stocking density with good quality pelleted feed, correct amount of fertilizers and better management practices could help to reduce the nutrients loss through the harvested water and bottom sediment.

\begin{tabular}{|l|l|l|l|}
\hline Parameters & Stocking density@ 7,500/ha & Stocking density@ 10, 000/ha & Stocking density@ 12, 500/ha \\
\hline pH & $8.0 \mathrm{a}$ & $7.6 \mathrm{a}, \mathrm{b}$ & $7.3 \mathrm{~b}$ \\
\hline Dissolved oxygen (mg/l) & $5.5 \mathrm{a}$ & $5.0 \mathrm{a}$ & $5.0 \mathrm{a}$ \\
\hline Ammonium nitrogen NH4-N (mg/l) & $0.04 \mathrm{a}$ & $0.08 \mathrm{~b}$ & $0.12 \mathrm{c}$ \\
\hline Nitrite nitrogen NO2-N (mg/l) & $0.03 \mathrm{a}$ & $0.04 \mathrm{a}$ & $0.08 \mathrm{~b}$ \\
\hline Nitrate nitrogen NO3-N (mg/l) & $0.10 \mathrm{a}$ & $0.14 \mathrm{a}$ & $0.20 \mathrm{~b}$ \\
\hline Orthophosphate PO4-P (mg/l) & $0.02 \mathrm{a}$ & $0.02 \mathrm{a}$ & $0.02 \mathrm{a}$ \\
\hline Total Phospahte (mg/l) & $0.03 \mathrm{a}$ & $0.03 \mathrm{a}$ & $0.05 \mathrm{a}$ \\
\hline Dissolved organic carbon DOC (mg/l) & $1.8 \mathrm{a}$ & $2.8 \mathrm{~b}$ & $4.0 \mathrm{c}$ \\
\hline Total alkalinity (mg/l as CaCO3) & $140 \mathrm{a}$ & $120 \mathrm{a}$ & $100 \mathrm{a}$ \\
\hline Turbidity (cm) & $18 \mathrm{a}$ & $16 \mathrm{a}, \mathrm{b}$ & $12 \mathrm{~b}$ \\
\hline Chlorophyll a (mg/l) & $0.20 \mathrm{a}$ & $0.30 \mathrm{~b}$ & $0.40 \mathrm{c}$ \\
\hline
\end{tabular}

Table 4: Average water quality parameters in the polyculture of Indian major carps. Values followed by the same superscript in a row are not significantly different at the 0.05 levels

\section{Acknowledgement}

The authors are grateful to the Director of the institute for his help to provide necessary facilities required for this study and constant encouragement.

\section{References}

1. Edwards P (1993) Environmental issues in integrated agricultureaquaculture and waste water-fed fish culture systems. In: R.S.V.Pullin edn. Environment and Aquaculture in Developing Countries, ICLARM Conf Proc 31: 139-170.

2. Lin CK, Yang Y, Diana JS (1997) The effects of pond management strategies on nutrient budgets: Thailand. Fourteenth Annual Technical Report, Pond Dynamics/Aquaculture CRSP, Oregon State University, Corvallis, Oregon, USA, 19-24.
3. Boyd CE (1985) Chemical budgets for channel catfish ponds. Trans Am Fish Soc 114: 291-298.

4. Daniels HV, Boyd CE (1989) Chemical budgets for polyethylene-lined, brackish water ponds. J World Aquacult Soc 20: 53-60.

5. Green BW, Boyd CE (1995) Chemical budgets for organically fertilized fish ponds in the dry tropics. World Aquac Soc 26: 284-296.

6. Hopkins JS, Hamilton RDI, Sandifer PA, Browdy CL, Stokes AD (1993) Effect of water exchange rate on production, water quality, effluent characteristics and nitrogen budgets of intensive shrimp ponds. J World Aquacult Soc 24: 304-320.

7. Martin JLM, Veran Y, Guelorget O, Pham D (1998) Shrimp rearing: stocking density, growth, impact on sediment, waste output and their relationships studied through the nitrogen budget in rearing ponds. Aquaculture, 164: 135-149.

8. Briggs MRP, Funge-Smith SJ (1994) A nutrient budget of some intensive marine shrimp ponds in Thailand. Aquac Fish Manage 25: 789-811. 
Citation: $\quad$ Adhikari S, Pani KC, Mishr B, Jena JK, Jayasankar P (2014) Carbon, Nitrogen and Phosphorus Budget for the Culture of Indian Major Carps with Different Stocking Density. Hydrol Current Res 5: 176. doi:10.4172/2157-7587.1000176

Page 6 of 6

9. Thakur DP, Lin CK (2003) Water quality and nutrient budget in closed shrimp (Penaeus monodon) culture systems. Aquacultural Engineering 27: 159-176

10. Wahab MA, Bergheim A, Braaten B (2003) Water quality and partial mass budget in extensive shrimp ponds in Bangladesh. Aquaculture 218: 413-423.

11. Paez-Osuna F, Guerrero-Galvan SR, Ruiz-Fernandez AC, EspinozaAngulo R (1997) Fluxes and mass balances of nutrients in a semiintensive shrimp farm in North-Western Mexico. Mar Pollut Bull 34: 290-297.

12. Raive A, Avnimelech Y (1979) Total nitrogen analysis in water, soil and plant material with persulphate oxidation. Water Research 13: 911-912.

13. APHA (1989) Standard methods for the examination of water and waste water, 17th edn. American Public Health Association, American Water Works Association, Water Pollution Control Federation, Washington, DC, USA.

14. Walkley A, Armstrong BI ( 1934) An Examination of Degtjareff Method for Determining Soil Organic Matter and a Proposed Modification of the Chromic Acid Titration Method. Soil Sci 37:29-37.

15. Mohanty M, Adhikari S, Mohanty P, Sarangi N (2009) Role of waterborne copper on survival, growth and feed intake of Indian major carp, Cirrhinus mrigala Hamilton. Bulletin of Environmental Contamination and Toxicology, 82: 559-563.

16. Rahman MM, Verdegem MCJ (2010) Effects of intra- and inter specific competition on diet, growth and behavior of Labeo calbasu (Hamilton) and Cirrhinus cirrhosus (Bloch). Applied Animal Behavioural Science 128: 103-108.

17. Weatherley AH (1976) Factors affecting maximization of fish growth. Journal of the Fisheries Research Board of Canada 22: 1046-1048.

18. Khatune-Jannat KM, Rahman MM, Bashar MA, Hasan MN, Ahamed F et al. (2012) Effects of stocking density on survival, growth and production of Thai Climbing Perch (Anabas testudineus) under fed ponds. Sains Malaysiana 41: 1205-1210.

19. Rahman MM, Verdegem MCJ, Nagelkerke LAJ, Wahab MA, Verreth JA (2008d) Swimming, grazing and social behavior of rohu Labeo rohita (Hamilton) and common carp Cyprinus carpio (L.) in tanks under fed and non-fed conditions. Applied Animal Behavioral Science 113: 255-264

20. Chien YH, Lai HT (1988) The effect of aged sediments and stocking density on freshwater prawn Macrobrachium rosenbergii culture. J World Aquaculture Soc 19: 22A-23A.

21. Avnimelech Y, McHenery JR, Ross DJ (1984) Decomposition of organic matter in lake sediments. Environmental Science and Technology 18: 5-11.

22. Diab S, Shilo M (1986) Transformations of nitrogen in sediments of fish ponds in Israel. Bamidgeh, 38: 67-88.

23. Shrestha MK, Lin CK (1996) Phosphorus fertilization strategy in fish ponds based on sediment phosphorus saturation level. Aquaculture 142: 207-219.

24. Paez-Osuna F, Guerrero-Galvan SR, Ruiz-Fernandez AC (1999) Discharge of nutrients from shrimp farming to coastal waters of the Gulf of California. Mar Pollut Bull 38: 585-592.

25. Cai C, Gu X, Huang H, Dai X, Ye Y et al. (2012) Water quality, nutrient budget, and pollutant loads in Chinese mitten crab (Eriocheir sinensis) farms around East Taihu Lake. Chinese Journal of Oceanology and Limnology 30: 29-36.

26. Phan LT, Bui TM, Nguyen TTT, Gooley GJ, Ingram BA et al. (2009) Current status of farming practices of striped catfish, Pangasianodon hypophthalmus in the Mekong Delta, Vietnam. Aquaculture 296: 227-236.

27. De Silva SS, Ingram BA, Nguyen PT, Bui TM, Gooley GJ et al. (2010) Estimation of nitrogen and phosphorus in effluent from the striped catfish farming sector in the Mekong Delta, Vietnam. Ambio 39: 504-514.

28. Cooley SR, Coles VJ, Subramanium, Yager PL (2007) Seasonal variations in the Amazon plume-related atmospheric carbon sink. Global Biogeochemical Cycles, 21.

29. Subramaniam A, Yager PL, Carpenter EJ, Mahaffey C, Bjorkman K et al. (2008) Amazon River enhances diazotrophy and carbon sequestration in the tropical North Atlantic Ocean. Proceedings of the National Academy of Sciences of the United States of America 105: 10460-10465. 